\title{
Article \\ Presence of Systemic Amyloidosis in Mice with Partial Deficiency in Pituitary Adenylate Cyclase-Activating Polypeptide (PACAP) in Aging
}

\author{
Jason Sparks ${ }^{1}$, Adel Jungling ${ }^{1}$, Gabriella Kiss ${ }^{2}$, Laszlo Hiripi ${ }^{3}$, Daniel Pham ${ }^{1}$, Andrea Tamas ${ }^{1}$, \\ Orsolya Hoffmann ${ }^{3}$, Sebastian Bardosi ${ }^{4}$, Attila Miseta ${ }^{2}$ and Dora Reglodi 1,5,*
}

Citation: Sparks, J.; Jungling, A.; Kiss, G.; Hiripi, L.; Pham, D.; Tamas, A.; Hoffmann, O.; Bardosi, S.; Miseta, A.; Reglodi, D. Presence of Systemic Amyloidosis in Mice with Partial Deficiency in Pituitary Adenylate Cyclase-Activating Polypeptide (PACAP) in Aging. Appl. Sci. 2021, 11, 7373. https://doi.org/10.3390/ app11167373

Academic Editor: Alexander E. Hramov

Received: 9 July 2021

Accepted: 2 August 2021

Published: 11 August 2021

Publisher's Note: MDPI stays neutral with regard to jurisdictional claims in published maps and institutional affiliations.

Copyright: (c) 2021 by the authors. Licensee MDPI, Basel, Switzerland. This article is an open access article distributed under the terms and conditions of the Creative Commons Attribution (CC BY) license (https:/ / creativecommons.org/licenses/by/ $4.0 /)$.
1 Department of Anatomy, MTA-PTE PACAP Research Team, University of Pecs Medical School, Szigeti ut 12, 7624 Pecs, Hungary; jason.sparks@aok.pte.hu (J.S.); junglingadel@gmail.com (A.J.); pham.dani77@gmail.com (D.P.); andreatamassz@gmail.com (A.T.)

2 Clinical Centre, Department of Laboratory Medicine, University of Pecs, Ifjuság ut 13, 7624 Pecs, Hungary; kiss.gabriella2@pte.hu (G.K.); attila.miseta@aok.pte.hu (A.M.)

3 Department of Animal Biotechnology, Institute for Genetics and Biotechnology, Hungarian University of Agriculture and Life Sciences, Pater Karoly u. 1, 2100 Godollo, Hungary; hiripi1@gmail.com (L.H.); hoffmann.orsolya.ivett@uni-mate.hu (O.H.)

4 Center for Histology, Cytology and Molecular Diagnostics, Max-Planck-Strasse 5, 54296 Trier, Germany; sbardosi@outlook.com

5 Szentagothai Research Center, University of Pecs, 7622 Pecs, Hungary

* Correspondence: dora.reglodi@aok.pte.hu; Tel.: +36-72-536000

\begin{abstract}
Pituitary adenylate cyclase-activating polypeptide (PACAP), a neuropeptide with widespread expression and general cytoprotective effects, is also involved in aging. Previously, we observed accelerated systemic senile amyloidosis in PACAP knockout (KO) mice. As mice partially lacking PACAP (heterozygous-HZ) show variable symptoms, here we investigated whether HZ mice have accelerated aging, completed with observations in PAC1 receptor $\mathrm{KO}$ mice. As we have limited data on qualitative or quantitative changes in the blood of PACAP-deficient mice, we investigated whether these changes could be in the background of the amyloidosis. Routine histological staining was used to examine amyloid deposits, rated on a severity scale $0-3$. Blood was collected from PACAP wild type/ $\mathrm{HZ}$ mice for complete blood analysis. In contrast to receptor $\mathrm{KO}$ mice showing no amyloidosis, histopathological analysis revealed severe deposits in PACAP HZ mice, with kidney, spleen, skin, and intestines being most affected. Increased cholesterol, lipoprotein levels, and differences in several blood count parameters were found in HZ mice. In summary, amyloidosis also develops in partial absence of PACAP, in contrast to the lack of its PAC1 receptor. In addition to the earlier identified inflammatory and degenerative disturbances, the alteration in lipid metabolism and bone marrow activity can also be additional factors leading to systemic degenerative processes.
\end{abstract}

Keywords: PACAP; deficiency; amyloidosis; PAC1 receptor; blood formation; aging; heterozygous

\section{Introduction}

Pituitary adenylate cyclase-activating polypeptide (PACAP) is a neuropeptide with 38 (PACAP38) or 27 (PACAP27) amino acid residues [1]. PACAP acts through specific PAC1 receptors and VPAC1, and VPAC2 receptors which also bind a related peptide, vasoactive intestinal peptide (VIP), with equal affinity. In addition to the receptorial mechanisms of action, PACAP is able to traverse biological barriers and act directly intracellularly, and it also transactivates other receptors [1,2]. The eight splice variants of the PAC1 receptor activate different signal transduction pathways. The most common pathway through which PACAP exerts its actions is the CAMP/protein kinase A pathway. The expression of the PACAP receptors has been described to show changes according to developmental stage and other environmental conditions [3-5]. The splice variants of the receptor, the 
different signaling pathways, and the other routes of action are responsible for the very diverse actions of the peptide. Among others, PACAP has been shown to play a role in several physiological processes, such as micturition [6], cardiac excitability [7], control of body weight [8], respiration [9], pain processes [10], cartilage metabolism [11] as well as addiction and stress-related behaviors [12]. PACAP acts as a growth factor and influences the development of the nervous system as well as peripheral organs. These effects include actions on neuronal mitosis, migration, myelination, and tissue differentiation [13-17]. In the periphery, PACAP plays a role in haemopoetic stem cell proliferation [18], and skeletal and immune development $[19,20]$.

Similar to developmental effects, PACAP plays a role in restorative processes in various injuries. This has been reviewed several times [21-27]. The main protective mechanisms include strong antiapoptotic and anti-inflammatory effects as well as antioxidant capacity of the peptide [22,25]. Previously, we hypothesized that the effects of PACAP against increased apoptosis, and that inflammation and oxidative stress could also be an important protective factor in aging. Indeed, we have found that mice lacking endogenous PACAP display an early onset systemic amyloidosis present in most organs [28]. Based on these observations, we proposed that PACAP gene-deficient animals could serve as a model of accelerated aging [29]. Much less is known about mice lacking the specific receptor of PACAP (PAC1 receptor). Some studies have been published on altered physiological and pathological reactions of these mice, but it is not known whether they show any aging-related signs [30,31].

The clinical importance of PACAP has been highlighted in several studies [32]. PACAP is upregulated in different injuries and diseases; furthermore, PACAP gene polymorphism has been associated with altered stress response [33,34]. Homozygous PACAP genedeficient mice are well known to react with increased injuries to harmful stimuli. This has been proven in dozens of pathological conditions $[22,35,36]$. However, complete PACAP deficiency has not been described in humans and is not likely to occur. Nevertheless, partial deficiency or decreased levels have already been described in humans. For example, decreased PACAP levels have been shown in posttraumatic stress disorder in female patients [33], and in the cerebrospinal fluid of multiple sclerosis patients [37]. Furthermore, Han and coworkers have measured significantly decreased PACAP levels in the cerebrospinal fluid and decreased peptide expression in the brains of Alzheimer's disease patients, correlating with the decline of cognitive performance [38,39]. Thus, as partial deficiency of PACAP is a more likely clinical scenario, studying heterozygous PACAP-deficient mice could give a valuable insight into possible clinical correlations. Only scarce data are available about heterozygous mice and aging. Ohtaki and colleagues have described the decrease in antioxidant capacity with a parallel increase in reactive oxygen species in aging heterozygous mice [40]. Regarding the eye, it has been found that, while heterozygous animals do not differ from wild type mice in tear secretion and corneal structure at young age, they develop dry eye symptoms with corneal keratinization and reduced tear secretion at older age [41]. As mentioned above, we have previously described a presenile systemic amyloidosis in homozygous aging PACAP-deficient mice leading to multi-organ failure and possibly responsible for the increased mortality of these mice [28]. Given the possible human relevance, the aim of the present study was to investigate whether a similar phenomenon can be observed in mice partially lacking PACAP. In addition, we investigated whether amyloidosis can also be found in PAC1 receptor-deficient mice.

\section{Materials and Methods}

\subsection{Animals}

Wild type (WT) and heterozygous (HZ) PACAP-deficient (on CD1 background), as well as WT (PAC1-R WT) and homozygous PAC1 receptor-deficient (PAC1-R KO, C57BL/6J background) mice were used in the present investigation. For the histological analysis, PACAP WT $(n=8)$ and PACAP HZ $(n=10)$; PAC1-R WT $(n=9)$ and PAC1-R KO $(n=3)$ mice were used, they were grouped into 3- to 12- (young) and 13- to 24-month-old (aging) 
groups. For the blood analysis, 3.5 months old PACAP WT ( $n=11)$ and PACAP HZ ( $n=11)$ mice were used. Maintenance, backcrossing for ten generations of the in-house-bred mice, and all experimental procedures were approved by the Animal Welfare Committee of the University of Pécs, and the National Scientific Ethical Committee on Animal Experimentation (ÁTET) at the Ministry of Agriculture, fully complied with the Decree No. 40/2013. (II. 14.) of the Hungarian Government and the EU Directive 2010/63/EU on the protection of animals used for scientific purposes (ethical permission numbers: BA02/2000-24/2011; BA02/2000-20/2006 [42,43]). Genotyping of PACAP WT and HZ mice was performed from tail samples at sacrifice using a Phire Animal Tissue Direct PCR Kit (Thermo Fisher Scientific, Waltham, MA, USA) [43]. The genotypes of PAC1 receptor KO mice were determined by PCR of the total genomic DNA extracted from mouse tails [44]. Isolated genomic DNA of each experimental animal was added to RedTaq readymix (Sigma Aldrich, St. Louis, MO, USA) containing primers p7 (5'-TGGGTTTGATGACTATGAGC- $\left.3^{\prime}\right)$, p8 (5'TGAGGGTGACGAGGGAGG TG-3'), and pNeo (5'-GCCTTCTATCGCCTTCTTGA-3') [45], according to the manufacturer's instructions. For PCR, an MJ Research PTC200 thermal cycler was used. Following a 3-min pre-incubation step at $95^{\circ} \mathrm{C}$, the following program was applied for 30 cycles: $95^{\circ} \mathrm{C}, 45 \mathrm{~s}$ denaturation; $58^{\circ} \mathrm{C}, 45 \mathrm{~s}$ annealing; $72{ }^{\circ} \mathrm{C}, 1 \mathrm{~min}$ extension. This was then followed by a $72{ }^{\circ} \mathrm{C}$ step for $5 \mathrm{~min}$ and subsequent cooling to $4{ }^{\circ} \mathrm{C}$. All PCR experiments were validated using positive and negative controls. DNA fragments were visualized by $1 \%$ agarose gel electrophoresis.

\subsection{Histological Analysis}

For histological analysis, young and aging WT ( $n=4$ and $n=4$, respectively) and PACAP HZ $(n=3, n=7$, respectively); PAC1-R WT $(n=9)$; and PAC1-R KO $(n=3)$ mice were used. Mice were sacrificed under isoflurane anesthesia (AErrane, Baxter, Budapest, Hungary). Removed organs and tissues were fixed in $4 \%$ buffered paraformaldehyde and embedded in paraffin. Three- $\mu \mathrm{m}$-thick sections were made and stained with routine histological staining (hematoxylin and eosin, H\&E) as well as with Congo red, a pathological marker for amyloid. Amyloid deposits appear as an eosinophilic homogenous mass with H\&E staining. The appearance of amyloid was confirmed with Congo staining, which shows deposits as a red-orange mass under normal light, and apple-green birefringence under polarized light. An amyloid index described in our previous study was used in the present investigation to provide a semi-quantitative scoring of Congo red-positive amyloid deposits. The amyloid scoring was the following [28]: 0: no amyloid; 1: slight focal deposits; 2: presence of moderate/severe focal or slight diffuse amyloid; and 3: with massive diffuse amyloid deposit. Previously, we presented that male and female scores combined as no gender differences had been observed [28]. A statistical comparison between groups was made with a non-parametric Mann-Whitney test.

\subsection{Blood Laboratory Analysis}

As morphological alterations were only found in PACAP HZ mice, but not PAC1 receptor-deficient mice, blood laboratory analysis was performed only in PACAP HZ mice and compared to WT animals. Blood from young ( 3 months old) PACAP HZ $(n=11)$ and WT mice $(n=11)$ was collected under isoflurane overdose into BD Vacutainer tubes with sodium heparin for plasma analysis or EDTA for routine complete blood count (Becton, Dickinson and Company, NJ, USA). $\mathrm{Na}^{+}$and $\mathrm{K}^{+}$ions, alkaline phosphatase (ALP), creatinine, cholesterol, triglyceride, and high- and low-density lipoprotein (HDL, LDL) were measured with a COBAS 8000 analyzer (Roche Ltd., Rotkreuz, Switzerland), while blood count was measured with a Sysmex XN-1000-V Multispecies Hematology Analyzer (Sysmex Hungaria, Budapest, Hungary). The following parameters were measured: white blood cell count (WBC), red blood cell count (RBC), hemoglobin concentration (HGB), hematocrit $(\mathrm{HCT})$, mean corpuscular volume (MCV), mean corpuscular hemoglobin $(\mathrm{MCH})$, mean corpuscular hemoglobin concentration (MCHC), platelet count measured with optical method (PLT\&Q), red cell distribution width—standard deviation (RDW-SD), red cell 
distribution width - coefficient of variation (RDW-CV), platelet distribution width (PDW), mean platelet volume (MPV), platelet large cell ratio (P-LCR), plateletcrit (PCT), nucleated red blood cell (NRBC), neutrophil granulocyte count (NEUT), lymphocyte count (LYMPH), monocyte count (MONO), eosinophil granulocyte count (EO), basophil granulocyte count (BASO), reticulocyte count (RET), immature reticulocyte fraction (IRF), reticulocytes with low fluorescence (LFR), reticulocytes with median fluorescence (MFR), reticulocytes with high fluorescence (HFR), and reticulocyte hemoglobin equivalent (RET-HE).

Statistical analysis of plasma parameters and blood count was performed using twoway ANOVA followed by Fisher's or Bonferroni's post hoc test, respectively. Differences were considered significant when $p<0.05$.

\section{Results}

\subsection{Histology}

Our histological results in PACAP HZ mice matched those described earlier in homozygous PACAP KO mice [28]. Amyloid deposits appeared at an early age and were more widespread in mice partially lacking PACAP compared to WTs. Most severely affected organs were spleen, intestines, esophagus, kidney, and skin (Figure 1). Amyloid scores in the esophagus, intestines, spleen, kidney, and skin were markedly and significantly higher in the HZ animals compared to WTs (Figure 2).

In contrast to the PACAP-deficient mice, PAC1 receptor-deficient animals showed no sign of amyloid deposits. Screening through all organs did not find any sign of amyloidosis in either young or aging individuals; all organs had a normal structure (Figure 1).

\subsection{Blood Plasma Analysis and Blood Count}

Results of the plasma analysis (Table 1) were similar to our earlier findings in homozygous PACAP KO mice [28]. Significant changes were observed in HDL, LDL, and total cholesterol levels. However, in contrast to the earlier described slight, but not statistically significant, increases in aging PACAP KO animals, $\mathrm{HZ}$ mice showed significant increases in these parameters (Chol: $2.21 \pm 0.09$ and $2.57 \pm 0.08 \mathrm{mmol} / \mathrm{L}$; LDL: $0.26 \pm 0.01$ and $0.37 \pm 0.02 ;$ HDL $1.86 \pm 0.08$ and $2.22 \pm 0.07$ in WT and HZ mice, respectively). Among the lipid parameters, no difference was observed in the TG levels. Other parameters were not altered either (creatinin, $\mathrm{Na}, \mathrm{K}, \mathrm{ALP}$ ).

Table 1. Plasma analysis of wild type (WT) and PACAP heterozygous (HZ) mice. Results are given in mean \pm S.E.M. ${ }^{* *} p<0.01,{ }^{* * *} p<0.001$ vs. WT mice.

\begin{tabular}{ccc}
\hline & PACAP WT Mice & PACAP HZ Mice \\
\hline Creatinin $(\mu \mathrm{mol} / \mathrm{L})$ & $9.50 \pm 1.64$ & $8.10 \pm 0.68$ \\
$\mathrm{Na}^{+}(\mathrm{mmol} / \mathrm{L})$ & $160 \pm 0.5$ & $157.10 \pm 0.6$ \\
$\mathrm{~K}^{+}(\mathrm{mmol} / \mathrm{L})$ & $4.13 \pm 0.09$ & $4.17 \pm 0.08$ \\
$\mathrm{ALP}(\mathrm{U} / \mathrm{L})$ & $51.20 \pm 2.1$ & $53.45 \pm 2.32$ \\
$\mathrm{Cholesterol}(\mathrm{mmol} / \mathrm{L})$ & $2.21 \pm 0.09$ & $2.57 \pm 0.08^{* *}$ \\
$\mathrm{TG}(\mathrm{mmol} / \mathrm{L})$ & $1.06 \pm 0.1$ & $0.91 \pm 0.07$ \\
$\mathrm{LDL}(\mathrm{mmol} / \mathrm{L})$ & $0.26 \pm 0.01$ & $0.37 \pm 0.02^{* * *}$ \\
$\mathrm{HDL}(\mathrm{mmol} / \mathrm{L})$ & $1.86 \pm 0.08$ & $2.22 \pm 0.07^{* *}$ \\
\hline
\end{tabular}




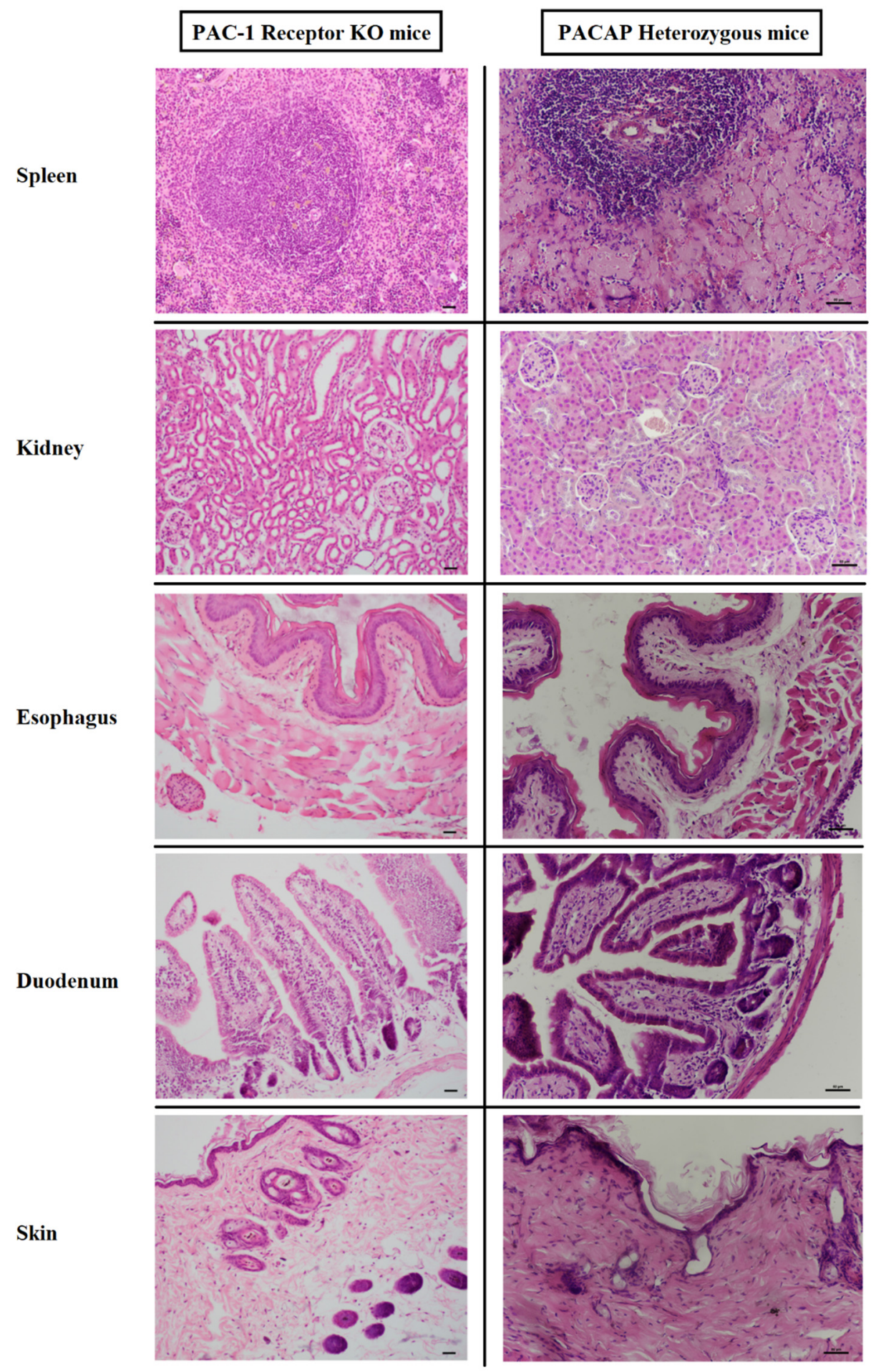

Figure 1. Representative photomicrographs of amyloid deposits in tissues from PAC1 receptor KO mice (left side) and from PACAP HZ mice (right side). Representative pictures from spleen, kidney, esophagus, duodenum, and skin are shown with HE staining. No amyloid deposits were found in receptor $\mathrm{KO}$ mice, while PACAP HZ mice showed severe deposits in the spleen parenchyme, in the renal corpuscles, in the lamina propria of esophagus and intestines, and in the subepidermal layer of the skin. Scale bar: 50 micrometers. 

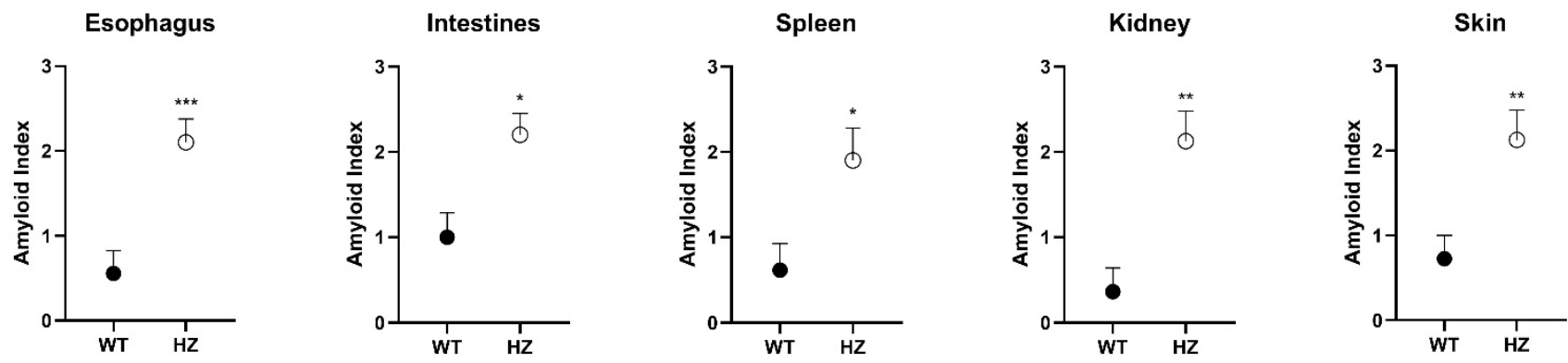

Figure 2. Overall amyloid index in young and aging WT and PACAP HZ mice in the most severely affected organs. Scores are represented as mean $+\mathrm{SEM},{ }^{*} p<0.05 ;{ }^{* *} p<0.01,{ }^{* * *} p<0.001$ compared to WT mice.

Earlier, we described that the complete blood count showed no significant alterations between WT and homozygous KO mice. This is different from our present observations. We found that, while most blood count parameters did not change (Figure 3), significant changes were observed in several of them (Table 2). Among characteristic parameters of red blood cells, significant changes were observed in mean corpuscular hemoglobin concentration (MCHC), red cell distribution width—standard deviation (RDW-SD), red cell distribution width - coefficient of variation (RDW-CV), nucleated red blood cell (NRBC), reticulocyte count (RET), reticulocytes with median fluorescence (MFR), and reticulocyte hemoglobin equivalent (RET-HE). Among the platelet parameters, plateletcrit was changed. No significant differences were observed in the other measured parameters, for details see Table 2.

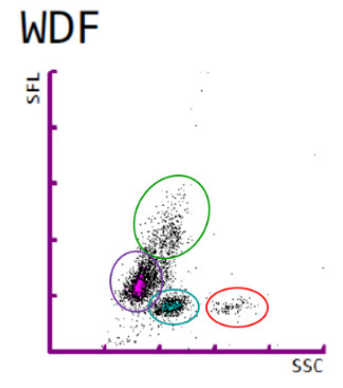

RBC

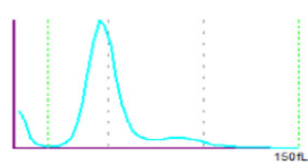

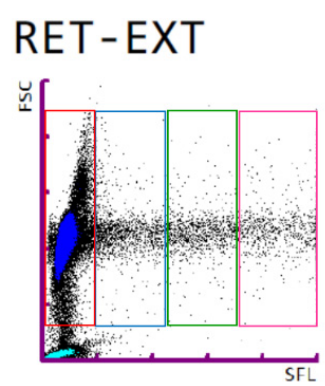

PLT

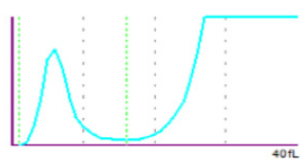

Figure 3. Representative blood count results from a HZ mouse. WDF: white blood cell differential; upper (green) cloud: monocytes, lower left (purple) cloud: lymphocytes, lower middle (blue) cloud: neutrophilic granulocytes, lower right (red) cloud: eosinophilic granulocytes. RET: reticulocytes and mature red blood cells, with the least differentiated reticulocytes in the right quartile, and mature red blood cells in the left quartile. Lower panels show representative red blood cell (RBC) and platelet (PLT) distribution width histograms. 
Table 2. Blood count in wild type (WT) and PACAP heterozygous (HZ) mice. Results are given in mean \pm S.E.M. ${ }^{*} p<0.05$, ** $p<0.01$ compared to wild type mice.

\begin{tabular}{|c|c|c|}
\hline & PACAP WT & PACAP HZ Mice \\
\hline White blood cell count (WBC) $\left[10^{9} / \mathrm{L}\right]$ & $3.56 \pm 0.42$ & $3.95 \pm 0.66$ \\
\hline Red blood cell count (RBC) $\left[10^{12} / \mathrm{L}\right]$ & $8.40 \pm 0.36$ & $7.91 \pm 0.20$ \\
\hline Hemoglobin concentration (HGB) $[\mathrm{g} / \mathrm{L}]$ & $123.91 \pm 3.36$ & $121.90 \pm 2.21$ \\
\hline Haematocrit (HCT) [\%] & $37.92 \pm 1.27$ & $36.31 \pm 0.80$ \\
\hline Mean corpuscular volume (MCV) [fL] & $45.50 \pm 1.16$ & $45.91 \pm 0.24$ \\
\hline Mean corpuscular hemoglobin $(\mathrm{MCH})[\mathrm{pg}]$ & $14.88 \pm 0.34$ & $15.45 \pm 0.15$ \\
\hline Mean corpuscular hemoglobin concetration $(\mathrm{MCHC})[\mathrm{g} / \mathrm{L}]$ & $327.64 \pm 3.05$ & $335.90 \pm 1.66^{*}$ \\
\hline Platelet count measured with optical method (PLT\&Q) $\left[10^{9} / \mathrm{L}\right]$ & $1324 \pm 260.25$ & $1394.1 \pm 66.01$ \\
\hline Red cell distribution width—standard deviation (RDW-SD) [fL] & $27.15 \pm 1.86$ & $23.2 \pm 0.24 *$ \\
\hline Red cell distribution width-coefficient of variation (RDW-CV) [\%] & $18.89 \pm 1.24$ & $15.87 \pm 0.31 *$ \\
\hline Platelet distribution width (PDW) [fL] & $7.06 \pm 0.15$ & $6.81 \pm 0.06$ \\
\hline Mean platelet volume (MPV) [fL] & $7.26 \pm 0.27$ & $6.93 \pm 0.03$ \\
\hline Platelet large cell ratio (P-LCR) [\%] & $9.62 \pm 3.05$ & $4.63 \pm 0.27$ \\
\hline Plateletcrit (PCT) [\%] & $0.75 \pm 0.09$ & $1.03 \pm 0.06^{* *}$ \\
\hline Nucleated red blood cell (NRBC) $\left[10^{9} / \mathrm{L}\right]$ & $0.06 \pm 0.01$ & $0.03 \pm 0.01^{* *}$ \\
\hline Neutrophil granulocyte count (NEUT) $\left[10^{9} / \mathrm{L}\right]$ & $0.93 \pm 0.12$ & $0.78 \pm 0.08$ \\
\hline Lymphocyte count $(\mathrm{LYMPH})\left[10^{9} / \mathrm{L}\right]$ & $2.16 \pm 0.28$ & $2.63 \pm 0.51$ \\
\hline Monocyte count $(\mathrm{MONO})\left[10^{9} / \mathrm{L}\right]$ & $0.30 \pm 0.04$ & $0.33 \pm 0.06$ \\
\hline Eosinophil garnulocyte count (EO) $\left[10^{9} / \mathrm{L}\right]$ & $0.15 \pm 0.01$ & $0.17 \pm 0.03$ \\
\hline Basophil granulocyte count (BASO) $\left[10^{9} / \mathrm{L}\right]$ & $0.00 \pm 0.00$ & $0.00 \pm 0.00$ \\
\hline Reticulocyte count (RET) [\%] & $4.19 \pm 0.19$ & $3.73 \pm 0.01 *$ \\
\hline Immature reticulocyte fraction (IRF) [\%] & $52.45 \pm 1.06$ & $51.26 \pm 0.46$ \\
\hline Reticulocytes with low fluorescence (LFR) [\%] & $47.55 \pm 1.06$ & $48.74 \pm 0.46$ \\
\hline Reticulocytes with median fluorescence (MFR) [\%] & $12.60 \pm 0.38$ & $11.10 \pm 0.16^{* *}$ \\
\hline Reticulocytes with high fluorescence (HFR) [\%] & $39.86 \pm 0.89$ & $40.16 \pm 0.53$ \\
\hline Reticulocyte hemoglobin equivalent (RET-HE) [pg] & $17.34 \pm 0.33$ & $18.45 \pm 0.08^{* *}$ \\
\hline
\end{tabular}

\section{Discussion}

In contrast to the severe symptoms observed in mice partially lacking PACAP, no sign of amyloidosis or other marked histological alteration in any organ could be observed in the PAC1 receptor knockout mice. The involvement of the PAC1 receptor has been proven in several physiological processes $[11,35,46,47]$. Accordingly, the lack of the receptor is expected to lead to severe alterations in these processes. Indeed, PAC1 receptor knockout mice display several pathological responses to certain stimuli, but compensatory mechanisms have also been implicated in cases where no alteration can be observed. Among others, PAC1 receptor knockout mice have blunted intestinal relaxation [48], decreased fertility [49], decreased calcium, oxytocin and vasopressin release from supraoptic neurons [50], impaired cardiorespiratory responses after birth [9,51,52], mild deficit in learning and memory with reduced expression of brain derived neurotrophic factor [53,54]. In addition, elevated locomotor behavior with reduced anxiety and altered social behavior $[55,56]$, decreased writhing response to pain as well as markedly reduced chronic nociceptive response $[57,58]$, pulmonary hypertension and right heart failure leading to early postnatal death [30], attenuated pupillary light reflex [59], and impaired insulinotropic response [45] have also been reported.

Interestingly, in spite of the several reported protective effects of the PAC1 receptor, PAC1 receptor deficiency has been found to attenuate progression of atherosclerosis in apolipoprotein E-deficient mice [31]. There are other controversial data on PAC1 deficiency. While Otto and coworkers [55] did not observe any gross alteration in circadian rhythmicity, others described altered VIP oscillation patterns during the dark period [60] phase delay after photic stimulations [61], and altered circadian food anticipatory activity rhythms [62]. Several reports have described no differences between PAC1 receptor-deficient and wild type mice: PAC1 receptor knockout mice had unaffected FSH, LH and prolactin synthesis [49], limited alteration in nociception after short-lasting stimuli [58], and showed no 
distinguishable signs from wild type mice at birth [30]. Our results can be added to this last group of observations, as we found no differences between WT and PAC1 receptor $\mathrm{KO}$ mice in organ morphology and gross appearance, even at older age. However, it has to be noted that the early postnatal mortality of the newborns was high, which made the breeding of the animals extremely complicated. The differences may depend on mouse strain, environmental conditions, and several other factors.

In contrast to PAC1 receptor $\mathrm{KO}$ mice, we found several alterations in PACAP-deficient animals. In the present study we aimed at investigating the effects of a partial lack of the peptide. Complete PACAP deficiency in PACAP homozygous knockout mice has been shown to have severe consequences in numerous physiological and pathological processes. Among others, mice with a complete lack of PACAP have high mortality, altered axonal arborization in the dentate gyrus [63], disturbed energy balance [64], and reduced food intake [65]. PACAP deficiency leads to increased vulnerability towards different stressors. This has been reviewed in numerous studies [22,66,67]. Among others, mice lacking endogenous PACAP show increased infarct volume in cerebral ischemia [68], increased damage in kidney ischemia/reperfusion injury [69], and increased ganglion cell death in retinal ischemia [70]. Moreover, regeneration after injuries is also slower, as it has been shown in axonal regeneration [71] and in callus formation following bone fracture [72]. These data support the protective role of endogenously expressed PACAP. Sporadic data support that even the partial lack of PACAP leads to increased injuries, but only a few papers have been published. Endo et al. have found a similar degree of retinal ganglion cell loss in retinal injury to that observed in homozygous PACAP-deficient mice [73]. In the present study we found that the presenile systemic amyloidosis observed in homozygous mice [28] is similarly severe to that in heterozygous animals. This shows the importance of the endogenous PACAPergic system in protection against age-related degenerative conditions, summarized in Figure 4. Recently, PACAP has been found to counteract tau deposition in a model of Alzheimer's disease, highlighting the importance of the PAC1/PACAP system in the clearance of tau in the brain [74]. This observation, together with our data in amyloidosis, shows that PACAP can act against pathological protein depositions, leading to degenerative diseases.

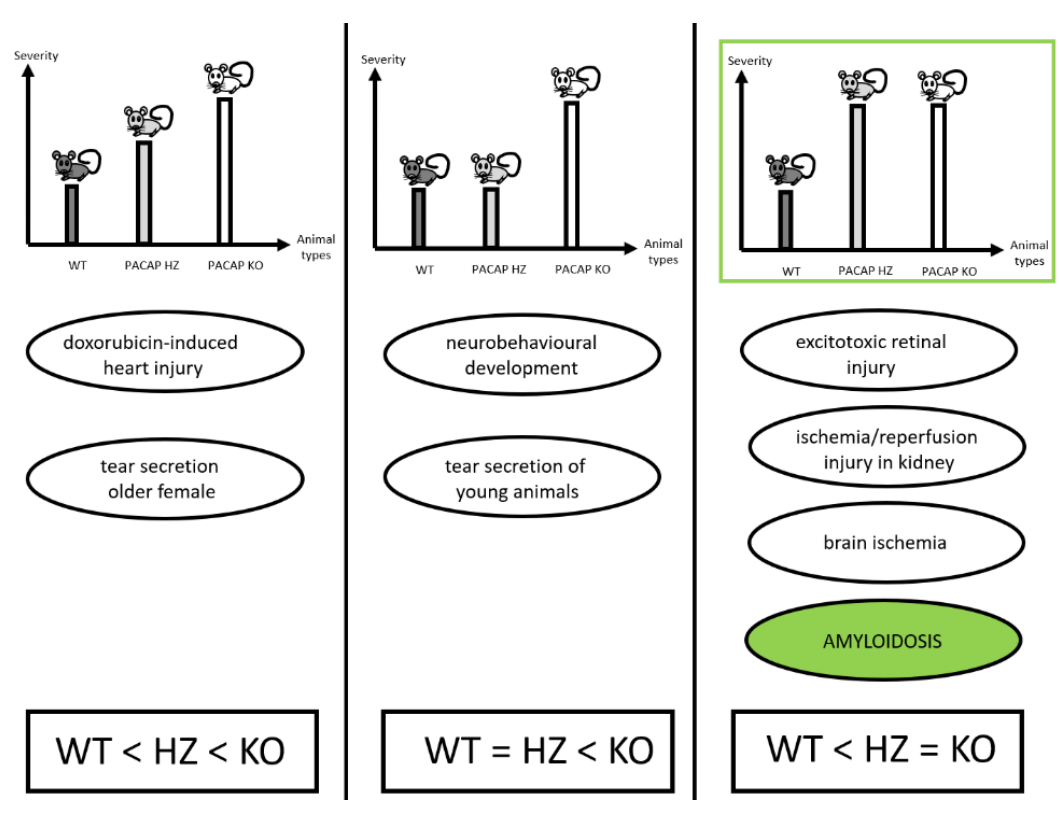

Figure 4. Summary of findings in PACAP HZ mice showing symptoms with different severity. In some reports, symptoms were between WT and KO mice in severity (left panel), while in others HZ mice were similar to WT animals (middle panel), and in some studies partial lack of PACAP was found to be sufficient to lead to severe symptoms, as observed in homozygous $\mathrm{KO}$ mice (right panel). Based on $[28,41,68-70,75]$. 
Among the laboratory parameters, we found that total cholesterol, LDL, and HDL levels were significantly increased in HZ mice compared to WT animals. This is in accordance with our earlier findings in homozygous mice, where we described a similar tendency in both young and aging groups. Although very few and partially contradicting data are available, PACAP has been implicated in several metabolic processes, including lipid metabolism. Among others, the early postnatal death of PACAP-deficient mice was shown to be associated with disturbed lipid metabolism, where authors found elevated serum triglyceride and cholesterol levels in PACAP null mice [76]. In addition, PACAP has been shown to increase adipocyte lipolysis [77-79], free fatty acid, and triglyceride levels, but no change was observed in cholesterol after infusion and bolus injection in dogs [80]. These and other related effects of PACAP in inflammatory processes may be in the background for the described accelerated atherosclerosis found in PACAP/Apolipoprotein E-deficient mice [81], although no change in cholesterol levels were found in these mice. PACAP was also found to ameliorate lipid metabolism and inflammation in fatty liver [82]. Total blood count showed no major differences between WT and HZ mice, but data from our young mice showed minor but statistically significant differences in parameters reflecting formation and maturation of red blood cells and platelets. Reticulocyte as well as nucleated red blood cell count was lower, while mean corpuscular hemoglobin concentration was higher, and plateletcrit was found to be slightly increased in HZ mice. Although we cannot draw final conclusions from these data, PACAP has already been demonstrated to be involved in hematopoiesis. The very limited data from the literature show, for example, that PACAP is involved in hematopoietic progenitor cell proliferation [18] and in megakaryocyte maturation $[83,84]$.

\section{Conclusions}

In conclusion, in the present study we provided evidence that presenile systemic amyloidosis develops also in the partial absence of PACAP, in contrast to the lack of its PAC1 receptor. In addition to the earlier identified inflammatory and degenerative disturbances, the alterations in lipid metabolism and bone marrow activity can also be seen as additional factors that lead to systemic degenerative processes.

Author Contributions: Conceptualization, D.R., A.T., S.B.; investigation, J.S., A.J., G.K., A.M., L.H., O.H., D.P., A.T., S.B., D.R.; writing J.S., A.J., D.R., A.T. All authors have read and agreed to the published version of the manuscript.

Funding: Supported by National Research, Development and Innovation Fund K135457, FK129190, K119759, National Brain Research Program NAP2017-1.2.1-NKP-2017-00002; MTA-TKI-14016; GINOP2.3.2-15-2016-00050 “PEPSYS"; EFOP-3.6.3-16-2017-00009; EFOP-3.6.1-16-2016-00004;, EFOP-3.6.2-162017-00008; "The role of neuroinflammation in neurodegeneration: from molecules to clinics"; Higher Education Institutional Excellence Programme of the Ministry of Human Capacities in Hungary: 20765/3/2018/FEKUTSTRAT, 2020-4.1.1-TKP2020-FIKP III.

Institutional Review Board Statement: This research was approved by the Animal Welfare Committee of the University of Pécs, and the National Scientific Ethical Committee on Animal Experimentation (ÁTET) at the Ministry of Agriculture, fully complied with the Decree No. 40/2013. (II. 14.) of the Hungarian Government and the EU Directive 2010/63/EU on the protection of animals used for scientific purposes (ethical permission numbers: BA02/2000-24/2011; BA02/2000-20/2006.

Informed Consent Statement: Not applicable.

Data Availability Statement: The data presented in this study are available in the article, there is no supplementary data.

Conflicts of Interest: The authors declare no conflict of interest. 


\section{References}

1. Vaudry, D.; Falluel-Morel, A.; Bourgault, S.; Basille, M.; Burel, D.; Wurtz, O.; Fournier, A.; Chow, B.K.C.; Hashimoto, H.; Galas, L.; et al. Pituitary Adenylate Cyclase-Activating Polypeptide and Its Receptors: 20 Years after the Discovery. Pharmacol. Rev. 2009, 61, 283-357. [CrossRef]

2. Moody, T.W.; Lee, L.; Jensen, R.T. The G Protein-Coupled Receptor PAC1 Regulates Transactivation of the Receptor Tyrosine Kinase HER3. J. Mol. Neurosci. 2020, 1-9. [CrossRef] [PubMed]

3. Nicot, A.; DiCicco-Bloom, E. Regulation of neuroblast mitosis is determined by PACAP receptor isoform expression. Proc. Natl. Acad. Sci. USA 2001, 98, 4758-4763. [CrossRef]

4. Lakk, M.; Szabo, B.; Volgyi, B.; Gabriel, R.; Denes, V. Development-related splicing regulates pituitary adenylate cyclase-activating polypeptide (PACAP) receptors in the retina. Investig. Ophthalmol. Vis. Sci. 2012, 53, 7825-7832. [CrossRef]

5. Dénes, V.; Czotter, N.; Lakk, M.; Berta, G.; Gabriel, R. PAC1-expressing structures of neural retina alter their PAC1 isoform splicing during postnatal development. Cell Tissue Res. 2014, 355, 279-288. [CrossRef] [PubMed]

6. Girard, B.M.; Campbell, S.E.; Beca, K.I.; Perkins, M.; Hsiang, H.; May, V.; Vizzard, M.A. Intrabladder PAC1 Receptor Antagonist, PACAP(6-38), Reduces Urinary Bladder Frequency and Pelvic Sensitivity in Mice Exposed to Repeated Variate Stress (RVS). J. Mol. Neurosci. 2020, 1-14. [CrossRef]

7. Parsons, R.L.; May, V. PACAP-Induced PAC1 Receptor Internalization and Recruitment of Endosomal Signaling Regulate Cardiac Neuron Excitability. J. Mol. Neurosci. 2018, 68, 340-347. [CrossRef]

8. Bozadjieva-Kramer, N.; Ross, R.A.; Johnson, D.Q.; Fenselau, H.; Haggerty, D.L.; Atwood, B.; Lowell, B.; Flak, J.N. The role of mediobasal hypothalamic PACAP in the control of body weight and metabolism. Endocrinology 2021, 162, 1-15. [CrossRef] [PubMed]

9. Shi, Y.; Stornetta, D.S.; Reklow, R.J.; Sahu, A.; Wabara, Y.; Nguyen, A.; Li, K.; Zhang, Y.; Perez-Reyes, E.; Ross, R.A.; et al. A brainstem peptide system activated at birth protects postnatal breathing. Nature 2021, 589, 426-430. [CrossRef]

10. Körtési, T.; Tuka, B.; Tajti, J.; Bagoly, T.; Fülöp, F.; Helyes, Z.; Vécsei, L. Kynurenic acid inhibits the electrical stimulation induced elevated pituitary adenylate cyclase-activating polypeptide expression in the TNC. Front. Neurol. 2018, 8, 745. [CrossRef]

11. Lauretta, G.; Ravalli, S.; Szychlinska, M.A.; Castorina, A.; Maugeri, G.; D'Amico, A.G.; D'Agata, V.; Musumeci, G. Current knowledge of pituitary adenylate cyclase activating polypeptide (PACAP) in articular cartilage. Histol. Histopathol. 2020, 35, 1251-1262. [CrossRef]

12. Gargiulo, A.T.; Pirino, B.E.; Curtis, G.R.; Barson, J.R. Effects of pituitary adenylate cyclase-activating polypeptide isoforms in nucleus accumbens subregions on ethanol drinking. Addict. Biol. 2020, 26, e12972. [CrossRef]

13. Maugeri, G.; D’Amico, A.; Musumeci, G.; Reglodi, D.; D’Agata, V. Effects of PACAP on Schwann cells: Focus on nerve injury. Int. J. Mol. Sci. 2020, 21, 8233. [CrossRef]

14. Hayata-Takano, A.; Kamo, T.; Kijima, H.; Seiriki, K.; Ogata, K.; Ago, Y.; Nakazawa, T.; Shintani, Y.; Higashino, K.; Nagayasu, K.; et al. Pituitary adenylate cyclase-activating polypeptide modulates dendritic spine maturation and morphogenesis via microRNA-132 upregulation. J. Neurosci. 2019, 39, 4208-4220. [CrossRef] [PubMed]

15. Watanabe, J.; Nakamachi, T.; Matsuno, R.; Hayashi, D.; Nakamura, M.; Kikuyama, S.; Nakajo, S.; Shioda, S. Localization, characterization and function of pituitary adenylate cyclase-activating polypeptide during brain development. Peptides 2007, 28, 1713-1719. [CrossRef]

16. Vincze, A.; Reglodi, D.; Helyes, Z.; Hashimoto, H.; Shintani, N.; Ábrahám, H. Role of endogenous pituitary adenylate cyclase activating polypeptide (PACAP) in myelination of the rodent brain: Lessons from PACAP-deficient mice. Int. J. Dev. Neurosci. 2011, 29, 923-935. [CrossRef]

17. Raoult, E.; Bénard, M.; Komuro, H.; Lebon, A.; Vivien, D.; Fournier, A.; Vaudry, H.; Vaudry, D.; Galas, L. Cortical-layer-specific effects of PACAP and tPA on interneuron migration during post-natal development of the cerebellum. J. Neurochem. 2014, 130, 241-254. [CrossRef]

18. Xu, Z.; Ohtaki, H.; Watanabe, J.; Miyamoto, K.; Murai, N.; Sasaki, S.; Matsumoto, M.; Hashimoto, H.; Hiraizumi, Y.; Numazawa, S.; et al. Pituitary adenylate cyclase-activating polypeptide (PACAP) contributes to the proliferation of hematopoietic progenitor cells in murine bone marrow via PACAP-specific receptor. Sci. Rep. 2016, 6, 22373. [CrossRef] [PubMed]

19. Abad, C.; Tan, Y.-V. Immunomodulatory Roles of PACAP and VIP: Lessons from knockout mice. J. Mol. Neurosci. 2018, 66, 102-113. [CrossRef]

20. Juhász, T.; Helgadottir, S.L.; Tamás, A.; Reglődi, D.; Zákány, R. PACAP and VIP signaling in chondrogenesis and osteogenesis. Peptides 2015, 66, 51-57. [CrossRef] [PubMed]

21. Maugeri, G.; D'Amico, A.G.; Morello, G.; Reglodi, D.; Cavallaro, S.; D'Agata, V. Differential Vulnerability of Oculomotor Versus Hypoglossal Nucleus During ALS: Involvement of PACAP. Front. Neurosci. 2020, 14, 805. [CrossRef] [PubMed]

22. Tóth, D.; Szabo, E.; Tamas, A.; Juhasz, T.; Horvath, G.; Fabian, E.; Opper, B.; Szabo, D.; Maugeri, G.; D’Amico, A.G.; et al. Protective Effects of PACAP in Peripheral Organs. Front. Endocrinol. 2020, 11, 377. [CrossRef] [PubMed]

23. Toth, D.; Tamas, A.; Reglodi, D. The neuroprotective and biomarker potential of PACAP in human traumatic brain injury. Int. J. Mol. Sci. 2020, 21, 827. [CrossRef]

24. Reglodi, D.; Renaud, J.; Tamas, A.; Tizabi, Y.; Socías, S.B.; Del-Bel, E.; Raisman-Vozari, R. Novel tactics for neuroprotection in Parkinson's disease: Role of antibiotics, polyphenols and neuropeptides. Prog. Neurobiol. 2017, 155, 120-148. [CrossRef] 
25. Reglodi, D.; Tamas, A.; Jungling, A.; Vaczy, A.; Rivnyak, A.; Fulop, B.; Szabo, E.; Lubics, A.; Atlasz, T. Protective effects of pituitary adenylate cyclase activating polypeptide against neurotoxic agents. Neurotoxicology 2018, 66, 185-194. [CrossRef]

26. Reglodi, D.; Tóth, D.; Vicena, V.; Manavalan, S.; Brown, D.; Getachew, B.; Tizabi, Y. Therapeutic potential of PACAP in alcohol toxicity. Neurochem. Int. 2019, 124, 238-244. [CrossRef] [PubMed]

27. Nonaka, N.; Banks, W.A.; Shioda, S. Pituitary adenylate cyclase-activating polypeptide: Protective effects in stroke and dementia. Peptides 2020, 130, 170332. [CrossRef]

28. Reglodi, D.; Jungling, A.; Longuespée, R.; Kriegsmann, J.; Casadonte, R.; Kriegsmann, M.; Juhasz, T.; Bardosi, S.; Tamas, A.; Fulop, B.D.; et al. Accelerated pre-senile systemic amyloidosis in PACAP knockout mice-A protective role of PACAP in age-related degenerative processes. J. Pathol. 2018, 245, 478-490. [CrossRef]

29. Reglodi, D.; Atlasz, T.; Szabo, E.; Jungling, A.; Tamas, A.; Juhasz, T.; Fulop, B.D.; Bardosi, A. PACAP deficiency as a model of aging. GeroScience 2018, 40, 437-452. [CrossRef]

30. Otto, C.; Hein, L.; Brede, M.; Jahns, R.; Engelhardt, S.; Gröne, H.-J.; Schütz, G. Pulmonary hypertension and right heart failure in pituitary adenylate cyclase-activating polypeptide type I receptor-deficient mice. Circulation 2004, 110, 3245-3251. [CrossRef]

31. Splitthoff, P.; Rasbach, E.; Neudert, P.; Bonaterra, G.A.; Schwarz, A.; Mey, L.; Schwarzbach, H.; Eiden, L.E.; Weihe, E.; Kinscherf, R. PAC1 deficiency attenuates progression of atherosclerosis in ApoE deficient mice under cholesterol-enriched diet. Immunobiology 2020, 225, 151930. [CrossRef] [PubMed]

32. Reglodi, D.; Helyes, Z.; Nemeth, J.; Vass, R.A.; Tamas, A. PACAP as a potential biomarker: Alterations of PACAP levels in human physiological and pathological conditions. In Pituitary Adenylate Cyclase Activating Polypeptide-PACAP (Current Topics in Neurotoxicity, 11); Reglodi, D., Tamas, A., Eds.; Springer: New York, NY, USA, 2016; pp. 815-832. [CrossRef]

33. Ressler, K.J.; Mercer, K.B.; Bradley, B.; Jovanovic, T.; Mahan, A.; Kerley, K.; Norrholm, S.D.; Kilaru, V.; Smith, A.K.; Myers, A.J.; et al. Post-traumatic stress disorder is associated with PACAP and the PAC1 receptor. Nature 2011, 470, 492-497. [CrossRef] [PubMed]

34. Somogyvari-Vigh, A.; Reglodi, D. Pituitary adenylate cyclase activating polypeptide: A potential neuroprotective peptide. Curr. Pharm. Des. 2004, 10, 2861-2889. [CrossRef]

35. D'Amico, A.G.; Maugeri, G.; Musumeci, G.; Reglodi, D.; D’Agata, V. PACAP and NAP: Effect of Two Functionally Related Peptides in Diabetic Retinopathy. J. Mol. Neurosci. 2021, 1-11. [CrossRef]

36. Zheng, Y.; Zhang, L.; Xie, J.; Shi, L. The emerging role of neuropeptides in Parkinson's disease. Front. Aging Neurosci. 2021, 13, 646726. [CrossRef] [PubMed]

37. Baranowska-Bik, A.; Kochanowski, J.; Uchman, D.; Wolinska-Witort, E.; Kalisz, M.; Martyńska, L.; Baranowska, B.; Bik, W. Vasoactive intestinal peptide (VIP) and pituitary adenylate cyclase activating polypeptide (PACAP) in humans with multiple sclerosis. J. Neuroimmunol. 2013, 263, 159-161. [CrossRef]

38. Han, P.; Liang, W.; Baxter, L.C.; Yin, J.; Tang, Z.; Beach, T.G.; Caselli, R.J.; Reiman, E.M.; Shi, J. Pituitary adenylate cyclase-activating polypeptide is reduced in Alzheimer disease. Neurology 2014, 82, 1724-1728. [CrossRef]

39. Han, P.; Caselli, R.J.; Baxter, L.; Serrano, G.; Yin, J.; Beach, T.G.; Reiman, E.M.; Shi, J. Association of pituitary adenylate cyclaseactivating polypeptide with cognitive decline in mild cognitive impairment due to Alzheimer disease. JAMA Neurol. 2015, 72, 333-339. [CrossRef]

40. Ohtaki, H.; Satoh, A.; Nakamachi, T.; Yofu, S.; Dohi, K.; Mori, H.; Ohara, K.; Miyamoto, K.; Hashimoto, H.; Shintani, N.; et al. Regulation of oxidative stress by pituitary adenylate cyclase-activating polypeptide (PACAP) mediated by PACAP receptor. $J$. Mol. Neurosci. 2010, 42, 397-403. [CrossRef]

41. Nakamachi, T.; Ohtaki, H.; Seki, T.; Yofu, S.; Kagami, N.; Hashimoto, H.; Shintani, N.; Baba, A.; Mark, L.; Lanekoff, I.; et al. PACAP suppresses dry eye signs by stimulating tear secretion. Nat. Commun. 2016, 7, 12034. [CrossRef]

42. Hashimoto, H.; Shintani, N.; Tanaka, K.; Mori, W.; Hirose, M.; Matsuda, T.; Sakaue, M.; Miyazaki, J.-I.; Niwa, H.; Tashiro, F.; et al. Altered psychomotor behaviors in mice lacking pituitary adenylate cyclase-activating polypeptide (PACAP). Proc. Natl. Acad. Sci. USA 2001, 98, 13355-13360. [CrossRef]

43. Farkas, J.; Kovács, L.; Gáspár, L.; Nafz, A.; Gaszner, T.; Ujvári, B.; Kormos, V.; Csernus, V.; Hashimoto, H.; Reglődi, D.; et al. Construct and face validity of a new model for the three-hit theory of depression using PACAP mutant mice on CD1 background. Neuroscience 2017, 354, 11-29. [CrossRef] [PubMed]

44. Laird, P.W.; Zijderveld, A.; Linders, K.; Rudnicki, M.A.; Jaenisch, R.; Berns, A. Simplified mammalian DNA isolation procedure. Nucleic Acids Res. 1991, 19, 4293. [CrossRef]

45. Jamen, F.; Persson, K.; Bertrand, G.; Rodriguez-Henche, N.; Puech, R.; Bockaert, J.; Ahrén, B.; Brabet, P. PAC1 receptor-deficient mice display impaired insulinotropic response to glucose and reduced glucose tolerance. J. Clin. Investig. 2000, 105, 1307-1315. [CrossRef] [PubMed]

46. May, V.; Johnson, G.C.; Hammack, S.E.; Braas, K.M.; Parsons, R.L. PAC1 Receptor Internalization and Endosomal MEK/ERK Activation Is Essential for PACAP-Mediated Neuronal Excitability. J. Mol. Neurosci. 2021, 1-7. [CrossRef]

47. Maugeri, G.; D'Amico, A.G.; Castrogiovanni, P.; Saccone, S.; Federico, C.; Reibaldi, M.; Russo, A.; Bonfiglio, V.; Avitabile, T.; Longo, A.; et al. PACAP through EGFR transactivation preserves human corneal endothelial integrity. J. Cell. Biochem. 2019, 120, 10097-10105. [CrossRef]

48. Ekblad, E.; Jongsma, H.; Brabet, P.; Bockaert, J.; Sundler, F. Characterization of intestinal receptors for VIP and PACAP in rat and in PAC1 receptor knockout mouse. Ann. N. Y. Acad. Sci. 2000, 921, 137-147. [CrossRef] 
49. Jamen, F.; Rodriguez-Henche, N.; Pralong, F.; Jegou, B.; Gaillard, R.; Bockaert, J.; Brabet, P. PAC1 null females display decreased fertility. Ann. N. Y. Acad. Sci. 2006, 921, 400-404. [CrossRef]

50. Jamen, F.; Alonso, G.; Shibuya, I.; Widmer, H.; Vacher, C.-M.; Calas, A.; Bockaert, J.; Brabet, P.; Dayanithi, G. Impaired somatodendritic responses to pituitary adenylate cyclase-activating polypeptide (PACAP) of supraoptic neurones in PACAP type I -receptor deficient mice. J. Neuroendocrinol. 2003, 15, 871-881. [CrossRef]

51. Barrett, K.T.; Hasan, S.U.; Scantlebury, M.H.; Wilson, R. Impaired neonatal cardiorespiratory responses to hypoxia in mice lacking PAC1 or VPAC2 receptors. Am. J. Physiol. Regul. Integr. Comp. Physiol. 2019, 316, R594-R606. [CrossRef] [PubMed]

52. Barrett, K.T.; Hasan, S.U.; Scantlebury, M.H.; Wilson, R.J.A. Impaired cardiorespiratory responses to hypercapnia in neonatal mice lacking PAC1 but not VPAC2 receptors. Am. J. Physiol. Regul. Integr. Comp. Physiol. 2021, 320, R116-R128. [CrossRef]

53. Sauvage, M.; Brabet, P.; Holsboer, F.; Bockaert, J.; Steckler, T. Mild deficits in mice lacking pituitary adenylate cyclase-activating polypeptide receptor type 1 (PAC1) performing on memory tasks. Mol. Brain Res. 2000, 84, 79-89. [CrossRef]

54. Zink, M.; Otto, C.; Zörner, B.; Zacher, C.; Schütz, G.; Henn, F.A.; Gass, P. Reduced expression of brain-derived neurotrophic factor in mice deficient for pituitary adenylate cyclase activating polypeptide type-I-receptor. Neurosci Lett. 2004, 360, 106-108. [CrossRef] [PubMed]

55. Otto, C.; Martin, M.; Wolfer, D.P.; Lipp, H.-P.; Maldonado, R.; Schütz, G. Altered emotional behavior in PACAP-type-I-receptordeficient mice. Mol. Brain Res. 2001, 92, 78-84. [CrossRef]

56. Nicot, A.; Otto, T.; Brabet, P.; DiCicco-Bloom, E.M. Altered social behavior in pituitary adenylate cyclase-activating polypeptide type I receptor-deficient mice. J. Neurosci. 2004, 24, 8786-8795. [CrossRef]

57. Martin, M.; Otto, C.; Santamarta, M.T.; Torrecilla, M.; Pineda, J.; Schütz, G.; Maldonado, R. Morphine withdrawal is modified in pituitary adenylate cyclase-activating polypeptide type I-receptor-deficient mice. Mol. Brain Res. 2003, 110, 109-118. [CrossRef]

58. Jongsma, H.; Pettersson, L.M.E.; Zhang, Y.-Z.; Reimer, M.K.; Kanje, M.; Waldenström, A.; Sundler, F.; Danielsen, N. Markedly reduced chronic nociceptive response in mice lacking the PAC1 receptor. NeuroReport 2001, 12, 2215-2219. [CrossRef]

59. Engelund, A.; Fahrenkrug, J.; Harrison, A.; Luuk, H.; Hannibal, J. Altered pupillary light reflex in PACAP receptor 1-deficient mice. Brain Res. 2012, 1453, 17-25. [CrossRef] [PubMed]

60. Georg, B.; Hannibal, J.; Fahrenkrug, J. Lack of the PAC1 receptor alters the circadian expression of VIP mRNA in the suprachiasmatic nucleus of mice. Brain Res. 2007, 1135, 52-57. [CrossRef] [PubMed]

61. Hannibal, J.; Jamen, F.; Nielsen, H.S.; Journot, L.; Brabet, P.; Fahrenkrug, J. Dissociation between light-induced phase shift of the circadian rhythm and clock gene expression in mice lacking the pituitary adenylate cyclase activating polypeptide type 1 receptor. J. Neurosci. 2001, 21, 4883-4890. [CrossRef]

62. Hannibal, J.; Georg, B.; Fahrenkrug, J. Altered circadian food anticipatory activity rhythms in PACAP receptor 1 (PAC1) deficient mice. PLoS ONE 2016, 11, e0146981. [CrossRef] [PubMed]

63. Yamada, K.; Matsuzaki, S.; Hattori, T.; Kuwahara, R.; Taniguchi, M.; Hashimoto, H.; Shintani, N.; Baba, A.; Kumamoto, N.; Yamada, K.; et al. Increased stathmin1 expression in the dentate gyrus of mice causes abnormal axonal arborizations. PLoS ONE 2010, 5, e8596. [CrossRef] [PubMed]

64. Maasz, G.; Pirger, Z.; Reglodi, D.; Petrovics, D.; Schmidt, J.; Kiss, P.; Rivnyak, A.; Hashimoto, H.; Avar, P.; Jambor, E.; et al. Comparative protein composition of the brains of PACAP-deficient mice using mass spectrometry-based proteomic analysis. $J$. Mol. Neurosci. 2014, 54, 310-319. [CrossRef]

65. Nguyen, T.T.; Kambe, Y.; Kurihara, T.; Nakamachi, T.; Shintani, N.; Hashimoto, H.; Miyata, A. Pituitary adenylate cyclaseactivating polypeptide in the ventromedial hypothalamus is responsible for food intake behavior by modulating the expression of Agouti-related peptide in mice. Mol. Neurobiol. 2020, 57, 2101-2114. [CrossRef]

66. Reglodi, D.; Kiss, P.; Szabadfi, K.; Atlasz, T.; Gabriel, R.; Horvath, G.; Szakaly, P.; Sandor, B.; Lubics, A.; Laszlo, E.; et al. PACAP is an endogenous protective factor-insights from PACAP-deficient mice. J. Mol. Neurosci. 2012, 48, 482-492. [CrossRef] [PubMed]

67. Reglodi, D.; Vaczy, A.; Beltrán, A.E.R.; MaassenVanDenBrink, A. Protective effects of PACAP in ischemia. J. Headache Pain 2018, 19, 19. [CrossRef] [PubMed]

68. Ohtaki, H.; Nakamachi, T.; Dohi, K.; Aizawa, Y.; Takaki, A.; Hodoyama, K.; Yofu, S.; Hashimoto, H.; Shintani, N.; Baba, A.; et al. Pituitary adenylate cyclase-activating polypeptide (PACAP) decreases ischemic neuronal cell death in association with IL-6. Proc. Natl. Acad. Sci. USA 2006, 103, 7488-7493. [CrossRef] [PubMed]

69. Szakaly, P.; Horvath, G.; Kiss, P.; Láśzló, E.; Farkas, J.; Furjes, G.; Nemeth, J.; Reglodi, D. Changes in pituitary adenylate cyclase-activating polypeptide following renal ischemia-reperfusion in rats. Transplant. Proc. 2010, 42, 2283-2286. [CrossRef] [PubMed]

70. Szabadfi, K.; Atlasz, T.; Kiss, P.; Danyadi, B.; Tamas, A.; Helyes, Z.; Hashimoto, H.; Shintani, N.; Baba, A.; Toth, G.; et al. Mice deficient in pituitary adenylate cyclase activating polypeptide (PACAP) are more susceptible to retinal ischemic injury in vivo. Neurotox. Res. 2012, 21, 41-48. [CrossRef] [PubMed]

71. Armstrong, B.; Abad, C.; Chhith, S.; Cheung-Lau, G.; Hajji, O.; Nobuta, H.; Waschek, J. Impaired nerve regeneration and enhanced neuroinflammatory response in mice lacking pituitary adenylyl cyclase activating peptide. Neuroscience 2008, 151, 63-73. [CrossRef] [PubMed]

72. Józsa, G.; Fülöp, B.D.; Kovács, L.; Czibere, B.; Szegeczki, V.; Kiss, T.; Hajdú, T.; Tamás, A.; Helyes, Z.; Zákány, R.; et al. Lack of pituitary adenylate cyclase-activating polypeptide (PACAP) disturbs callus formation. J. Mol. Neurosci. 2019, 1-13. [CrossRef] 
73. Endo, K.; Nakamachi, T.; Seki, T.; Kagami, N.; Wada, Y.; Nakamura, K.; Kishimoto, K.; Hori, M.; Tsuchikawa, D.; Shinntani, N.; et al. Neuroprotective effect of PACAP against NMDA-induced retinal damage in the mouse. J. Mol. Neurosci. 2011, 43, 22-29. [CrossRef]

74. Schaler, A.W.; Runyan, A.M.; Clelland, C.L.; Sydney, E.J.; Fowler, S.L.; Figueroa, H.Y.; Shioda, S.; Santa-Maria, I.; Duff, K.E.; Myeku, N. PAC1 receptor-mediated clearance of tau in postsynaptic compartments attenuates tau pathology in mouse brain. Sci. Transl. Med. 2021, 13, eaba7394. [CrossRef]

75. Mori, H.; Nakamachi, T.; Ohtaki, H.; Yofu, S.; Sato, A.; Endo, K.; Iso, Y.; Suzuki, H.; Takeyama, Y.; Shintani, N.; et al. Cardioprotective effect of endogenous pituitary adenylate cyclase-activating polypeptide on Doxorubicin-induced cardiomyopathy in mice. Circ. J. 2010, 74, 1183-1190. [CrossRef] [PubMed]

76. Gray, S.L.; Cummings, K.J.; Jirik, F.R.; Sherwood, N.M. Targeted disruption of the pituitary adenylate cyclase-activating polypeptide gene results in early postnatal death associated with dysfunction of lipid and carbohydrate metabolism. Mol. Endocrinol. 2001, 15, 1739-1747. [CrossRef] [PubMed]

77. Åkesson, L.; Ahrén, B.; Manganiello, V.C.; Holst, L.S.; Edgren, G.; Degerman, E. Dual effects of pituitary adenylate cyclaseactivating polypeptide and isoproterenol on lipid metabolism and signaling in primary rat adipocytes. Endocrinology 2003, 144, 5293-5299. [CrossRef] [PubMed]

78. Åkesson, L.; Ahren, B.; Edgren, G.; Degerman, E. VPAC2-R mediates the lipolytic effects of pituitary adenylate cyclase-activating polypeptide/vasoactive intestinal polypeptide in primary rat adipocytes. Endocrinology 2005, 146, 744-750. [CrossRef]

79. Prandota, J. Possible pathomechanisms of sudden infant death syndrome: Key role of chronic hypoxia, infection/inflammation states, cytokine irregularities, and metabolic trauma in genetically predisposed infants. Am. J. Ther. 2004, 11, 517-546. [CrossRef] [PubMed]

80. Kawai, K.; Yokota, C.; Ohashi, S.; Isobe, K.; Suzuki, S.; Nakai, T.; Yamashita, K. Pituitary adenylate cyclase-activating polypeptide: Effects on pancreatic-adrenal hormone secretion and glucose-lipid metabolism in normal conscious dogs. Metabolism 1994, 43, 739-744. [CrossRef]

81. Rasbach, E.; Splitthoff, P.; Bonaterra, G.A.; Schwarz, A.; Mey, L.; Schwarzbach, H.; Eiden, L.E.; Weihe, E.; Kinscherf, R. PACAP deficiency aggravates atherosclerosis in ApoE deficient mice. Immunobiology 2019, 224, 124-132. [CrossRef] [PubMed]

82. Xiao, X.; Qiu, P.; Gong, H.; Chen, X.; Sun, Y.; Hong, A.; Ma, Y. PACAP ameliorates hepatic metabolism and inflammation through up-regulating FAIM in obesity. J. Cell. Mol. Med. 2019, 23, 5970-5980. [CrossRef] [PubMed]

83. Freson, K.; Peeters, K.; De Vos, R.; Wittevrongel, C.; Thys, C.; Hoylaerts, M.F.; Vermylen, J.; Van Geet, C. PACAP and its receptor VPAC1 regulate megakaryocyte maturation: Therapeutic implications. Blood 2008, 111, 1885-1893. [CrossRef] [PubMed]

84. Peeters, K.; Loyen, S.; Van Kerckhoven, S.; Stoffels, K.; Hoylaerts, M.F.; Van Geet, C.; Freson, K. Thrombopoietic effect of VPAC1 inhibition during megakaryopoiesis. Br. J. Haematol. 2010, 151, 54-61. [CrossRef] [PubMed] 